\title{
Women's Access to Higher Education in India
}

\author{
M. Sowjanya S. Shetty ${ }^{1}$ and Ramesh Salian ${ }^{2}$ \\ ${ }^{1}$ Research Scholar, ${ }^{2}$ Chairman, \\ Department of Economics, University College of Arts, Tumkur University, Tumkur, Karnataka, India \\ E-Mail: sowjanya936@gmail.com, salianramesh@hotmail.com
}

\begin{abstract}
Human capital is the most precious of all recourses which is core for the development of a nation. Higher education is regarded as the basis for the foundation for human development. It has constantpositive impact on development as they help in reducing unemployment and poverty which are hurdle in the path of Economic development. Higher education enhances people's capacity to work and their opportunities to work; promoting innovation ensures work satisfaction and also increases productivity there by cotrubuting to national development. Women frame an indispensable human capital for enhancing economic power of a nation. It is rather unfortunate that women, powerful human resource constituting half of India's total population and yet the country has one of the biggest gender gap in the world (101 in 136 Countries). This mirrors the status of women in India and gender discrimination in all aspects of life education, economic activity and empowerment. The representation of women in higher education management validate the the fact that half of the human resource is not optimally utilized. Progress of a society is possible only when its citizens are educated, dynamic, resourceful, enterprising, responsible and so forth. Without such citizens, development of a country can hardly be achieved in any field. This paper attempts to study specifically the major factors affecting enrolment of women in higher education in India.
\end{abstract}

Keywords: Gender Equality, Higher Education, India, Women

\section{INTRODUCTION}

Women constitute half of the human resource and are key to the economic aspirations of a nation. They are the most relevant untapped resources, the prodigy of female chunk in the economic activity is one of the major issue for the developing economies. According to World Bank estimates the working age population (15 to 59) is set to increase by more than 200 million in India in the next two decades, while its expected to decline in most developing economies of the world including China. But India may fail to obtain benefits without the participation of women, who form a major mass of the society. Development to be complete should involve all sections of the society without any discrimination. Even after seventy years of Independence, India's development is slow due to the lack of women's participation. Women are often invisible in the development scenario. Development process without the participation of women, who form a significant chunk of the society, will be lopsided. Higher education reduces inequalities, gender biases and encourages women to make a good society and to become the most active part of the economy. Gender discrimination is entrenched in the social fabric of Indian society which starts from the womb with sex determination tests, discrimination starts even before birth in some regions where boys are preferred to girls. They are often denied equal opportunities in terms of education, monetary return for their work, financial opportunities, inheritance of wealth and opportunities of the decision making at the family level. The subordination of women in the society and persistent stratification in Education resulted in nagging of gender equality. Marginality of women in education is effectively maintained. Higher education empowers women to equip with the ability to enable them to explore the world and partake fully in the development process.

Skilled human resource is vital for inclusive growth. Globalization necessitates development of human resource to meet the international standards, knowledge assimilated through education becomes vital. India is endowed with human resources which can be enlightened and empowered through development of education. Higher education ensures equitable economic development as it has unique quality, which is beneficial to the whole economy. The constitution of India guarantees equality to women but illiteracy and lack of awareness of their constitutional rights often put women to disadvantage. Education is a human right and an essential tool for achieving the goals of equality and development. Education reduces inequalities and functions as a means of improving their status within the family and in scoiety. It plays a crucial role in empowering women. Empowerment and capacity building provides women an avenue to acquire practical information and learning for their improved livelihoods. India can become a developed nation only if women contribute to the best of her capacity and ability which is possible when she is educated and empowered.

\section{OBJECTIVES OF THE STUDY}

1. To examine the trends in enrolment of women in higher education institutions in India over the years.

2. To discuss the Challenges faced in enrolment of women in higher education India.

3. To discuss the major factors hindering enrolmentof women in higher education

\section{METHODOLOGY}

The present study is based on the collection of data from secondary sources. Secondary data are obtained from 
various published and unpublished records, books, magazines and journals, both print and online.

\section{CONCEPTUAL AND OPERATIONAL FRAMEWORK}

A. Higher Education: Education in general and higher education in particular has occupied a prime place in the modern era. Education is the source to weed out the orthodox society of literacy all over the world while higher education enables an individual and thereof a society to transform towards a knowledge society. Therefore, higher education is no longer a choice either for an individual or for a state. It is an imperative tool to realise knowledge economy and society. The development of human resource depends on quality education. The expenditure on education in general and higher education in particular gives benefits to a Nation for stable economic growth, out space in technology and stability in economy. Higher education provides out space in technology and development of skills in human resources. Selection of a career or occupation for life may be influenced by several factors such as social characteristics, family income, parental education and occupation, personal interest abilities and higher education. Higher education is a factor which is pivotal to national progress and upliftment as education helps in moulding able, responsible and competent citizens apart from contributing in personality development of the individuals by inculcating certain values. In the development of a country like India, primary education helps in creating the base while higher education is important for providing the cutting edge. While India has third largest highrt education system in the world but it is accessed only by 12 per cent of the youth, it is deprived to large section particularly women.

\section{REVIEW OF LITERATURE}

Women constitute $49 \%$ in total population. However, the status of Indian women is not pleasing. Development of women is decisive to the economic progress of any Nation. India being male dominated society women generally faced all types of fences. For realising the objectives of the harmonious development of the country, women should go hand in hand with men, which necessitates empowerment of women and for empowering the women, education and skill development will play a vibrant role. The marginalised sections of the society, especially women, have inadequate admittance to education. In India, there are gender-based educational discrepancies. Higher education has been identified as an essential device for plummeting socioeconomic disparities and building an inclusive society.

Education improves women"s ability to resist subjugation and capacity to deal with outside world by overcoming barriers towards materialising their economic potential (Kabeer, 2005). Women play a very significant role in the development of the country. So we cannot ignore the role of education in the reference to women empowerment. The empowerment of women in India has been obstructed for centuries owing the various reasons amongst which the initial blow was in the form of depriving women from basic educational facilities (Sandhya, 2015).

Higher Education is one of the most important means of empowering women with the knowledge, skills and selfconfidence necessary to participate fully in the development process. (Hussain F \& Jadhav. M S 2013).

Gender Gap index 2013 (GGI) measures the gap between men and women in four fundamental categories - economic participation \& opportunity, educational attainment, health \& survival and political empowerment. India ranks among the lowest 101 in 136 Countries, below Countries like China, Sri Lanka and Bangladesh. This mirrors the status of women in India and gender discrimination in all aspects of life-education, economic activity and empowerment (Balve, 2015).

Higher education assists in empowering womenas qualified women tend to become leaders in society and it permits them to become role models for younger girls. It also enables women to choose domains of expertiseas decision makers through influence on policy related issues to social, economic, and cultural development, or by their participation in family and community life. (Shaukat \& Pell 2015).

Educated women have a greater sense of control over their lives and more power and control over resources within the family as compared to uneducated women. They get social recognition, which helps them to get insight of and have an awareness of what is undesirable and unfavourable about their current situation. The educated woman can perceive a better situation by realizing what is within her reach and what she should do to affect the improvement (Usha \& Sharma, 2001).

\section{A. Women Participation in Higher Education: Need and Trends}

Lack of education is the root cause for women's exploitation and negligence. Only literacy and education can help women to understand the Indian's constitutional and legislative provisions that are made to strengthen them. Education is "potential affirming and performance confirming". A few women are currently holding powerful positions in India and in the world, but there is still room for improvement if more women are educated. Perhaps with increase in women holding the mantle in a male-dominated political arena, the socio-political state of affairs of the whole world will definitely improve. Gender equity is what women desire. Educational attainment, social participation and economic involvement in deicison making are the key elements in ensuring the empowerment of women. Higher Education reduces inequalities, gender biasness and encourages women to make good society and to become the strongest part of the economy. Education empowers women to equips with the ability to enable them to explore the world partake fully in the development process. Economic empowerment develops their capability to impact, transform or form a better nation.(Shetty and Salian 2017) 
TABLE I NUMBER OF WOMEN COLLEGES IN INDIA

\begin{tabular}{|c|c|c|c|}
\hline Year & $\begin{array}{c}\text { Total } \\
\text { Colleges } \\
\text { in India }\end{array}$ & $\begin{array}{c}\text { Total Women } \\
\text { Colleges in } \\
\text { India }\end{array}$ & $\begin{array}{c}\text { \% of Women } \\
\text { Colleges in Respect of } \\
\text { Total College in India }\end{array}$ \\
\hline $1990-91$ & 7346 & 874 & 11.90 \\
\hline $2000-01$ & 12806 & 1578 & 12.32 \\
\hline $2010-11$ & 33023 & 3982 & 12.06 \\
\hline $2011-12$ & 35539 & 4266 & 12.00 \\
\hline
\end{tabular}

Source: UGC Annual Report, Annual Report of Department of Higher

Education

Table I shows that, maximum number of women's colleges were established in the period of 2011-12 it was 4266. It indicates there is increase in the number educational institutions for promoting higher education of women in India which has a direct relation with enrolment.

\begin{tabular}{l} 
TABLE II ENROLMENT OF WOMEN IN HIGHER EDUCATION IN \\
$\qquad$\begin{tabular}{|c|c|}
\hline INDIA PER HUNDRED MEN \\
\hline $1950-51$ & $\begin{array}{c}\text { Enrolment of } \\
\text { women per 100 men }\end{array}$ \\
\hline $1960-61$ & 13 \\
\hline $1970-71$ & 21 \\
\hline $1980-81$ & 28 \\
\hline $1990-91$ & 36 \\
\hline $2000-01$ & 46 \\
\hline $2005-06$ & 58 \\
\hline $2010-11$ & 62 \\
\hline $2011-12$ & 78 \\
\hline $2015-16$ & 80 \\
\hline
\end{tabular} \\
Source: compiled from Ministry of HRD, Educational \\
\hline
\end{tabular}

Table II indicates the increase in the enrolment of women per 100 men in higher education over the years. Level of education is the basic indicator of the development of society. Higher education is the key to economic sustainability and growth of the nation. Higher education plays a vital role to civilize society and also make the society live a sophisticated life style.

TABLE III ENROLMENT IN HIGHER EDUCATION IN DIFFERENT COURSES IN INDIA

\begin{tabular}{|l|c|c|c|c|}
\hline \multicolumn{1}{|c|}{ Level } & $\begin{array}{c}\text { Total (2013- } \\
\text { 14) }\end{array}$ & $\begin{array}{c}\text { \% share of } \\
\text { Women }\end{array}$ & $\begin{array}{c}\text { Total (2014- } \\
\text { 15) }\end{array}$ & $\begin{array}{c}\text { \% Share of } \\
\text { Women }\end{array}$ \\
\hline Graduate & $20,229,592$ & 85.12 & $22,933,295$ & 86.26 \\
\hline $\begin{array}{l}\text { Post } \\
\text { Graduate }\end{array}$ & $2,934,989$ & 12.35 & $29,466,709$ & 11.09 \\
\hline Research & 200,730 & 0.85 & 178,781 & 0.67 \\
\hline $\begin{array}{l}\text { Diploma/ } \\
\text { Certificate }\end{array}$ & 399,649 & 1.68 & 416,979 & 1.57 \\
\hline $\begin{array}{l}\text { Grand } \\
\text { Total }\end{array}$ & $23,764,960$ & 100 & $26,585,437$ & 100 \\
\hline
\end{tabular}

Source: Compiled University Grants Commission, Annual Report 2013-14,

2014-15

The above table shows the participation of women in different courses in higher education. There is increase in the number of women graduates while compared to post graduates and other technical education.

\section{B. Impediments}

Women continue to live in a state of neglect and exploitation. The development of any country mostly depends upon the expansion and dissemination of education in society. Increasing in the literacy rate cannot be referred as an indicator of progress because literacy implies ability to read or write. It is essential for women to provide access to higher education as higher education leads to value addition in individuals. There are several obstacles in way of women in pursuing education

1. Gender inequality

2. Conservative mindset

3. Early marriages

4. Family restrictions

5. Limited access to quality education in rural areas

6. Long distance schools and lack of public transport

7. Lack of motivated teachers

8. Non-availability of basic infrastructure like buildings, electricity etc

9. Lack of sanitary facilities

10. Restrictions on mobility

11. False perceptions

12. Limited employment opportunities

13. Limited access to appropriate reading materials.

Non availability of educational institutions nearby, lack of basic infrastructure makes travelling an obstacle to pusue higher education. Travel is also seen as a threat to personal security. This is a particularly strong factor in deterring girls from entering higher education as institutions are likely to be very distant and even if boarding facilities are available there are possible incidents of sexual harassment and sexual abuse to consider (Sathar \& Haque, 2000; World Bank, 2007; UNESCO, 2010).

\section{Initiatives}

There are several schemes introduced by the government for development of women, operated by different department and ministries. The efforts of government and its different agencies are ably supplemented by non-governmental organisations are playing an equally important role in facilitating women empowerment. Despite concerted efforts of governments and NGOs there are gaps. It is necessary to view the status of women in India in the era of inclusive growth in terms of some key constituents which ensures women empowerment like education, health and nutrition, sex ratio, economic participation, incidence of violence against women, participation in decision making, economic and political issues.

Gender inequalities in education and employment have intensely damaging consequences for the life probabilities of individuals and national economies. Higher education and training must be provided to women ensuring that they feel respected, confident and safe so that they can develop to their full potential. Investing in educational policies and programmes opens rich avenues for the advancement of 
women at all levels, across all business areas, which encourage women to enter the non-traditional sector. Higher education enables women to become more productive both inside and outside the household. Empowered women will be able to face the challenges of society and could stand for right happenings and against wrong happenings, so women education has a significant relation to women empowerment. With the increase in the number of women getting educated, there is considerable awareness among women to be decision makers and gradually the role of women is changing in the society as,,women in development $^{\text {ee }}$ to ,women-led development ${ }^{\text {ee }}$ Higher education and empowerment are the indicators of development, it is essential to increase the productivity of human capital.

We must find routes to bridge gender gap, one such being higher education. Higher education makes women economically sound which is source of empowering women. The eleventh five year plan "Towards Faster and More Inclusive Growth" aimed to attain gender inclusive growth in terms of benefits flowing through more employment and income to women who have been bypassed by higher rates of economic growth in recent years.

\section{SUGGESTIONS}

If women who represent 48 per cent of the population are given access to attain knowledge, develop skill which helps in eliminating the subordination of women in the society and become equal partners in the development of a nation. Education has been recognized as a fundamental right for every citizen of India. Higher education is one of the most important factors for the achievement of rapid economic development and technological progress.

1. Encourage skill oriented education use of ICT tools, use of internetfor the study and research by women.

2. Emphasise on value-based and value-oriented education to help realise the goals of entrepreneurship and empowerment, without sacrificing ethical standards.

3. Provision of attractive scholarship for meritorious and financially backward students to encourage higher studies.

4. Provision of financial assistance for female students through bank loans.

5. Establishment of institutes of higher studies for women in rural and remote areas.

6. Develop infrastructure which supports economic growth through balanced regional and sectoral growth.

7. Address the three overarching challenges: excellence, equity and expansion via Corporate Social Responsibility.

8. Awareness of female education is essential. It is said that "educated mothers educate family which results in educated population of a nation which builds strong nation".

9. Proper implementation of schemes provided by the government should be done by respective agencies.
10. Creation of Self-Employment Opportunities and WageEmployment Opportunities through financial assistance

11. Introduce sense of analysing which will support wider reforms in support of gender equality, involving men counter parts too.

\section{CONCLUSION}

Higher education has been identifies as a powerful tool in eliminating gender disparity, making individual competent to overcome evils of society and acts as a catalyist to uplift the status of women in the society. Gross enrolment ratio indicates improvement in enrolment of women in higher education but the rate of increase is still insufficient to eradicate gender disparity. The fruits of education are not enjoyed by women only but it passes on to her family and society. So women access in the domain of higher education is needed to be increased, the rate of increase is slow in almost all the Indian states. Higher education alone is capable of eradicating socio economic disparities and contribute in building an inclusive society. Sustainable growth of India depends on positive socio-economic transformation with men and women as partners in progress, reinforcing each other's effort in removing barriers to inclusive growth.

\section{REFERENCES}

[1] Retrieved from All India Survey on Higher Education, MHRD, Govt. of India: www.aishe.gov.in

[2] Retrieved from All India Women's Education Fund Association (AIWEFA) (2015).Women, Education, Skills and Work. Compendium: Case Studies from India.

[3] Balve S. (2015). Women Entrepreneurship towards women Empowerment in India: plan Initiatives. Southern Economist, 54(3): 11-16.

[4] Kabeer (2005) Gender equality and womens empowerment: $A$ critical analysis of thethird millennium development goal Gender and development, 13(1), 13-24

[5] Hussain, F., \& Jadhav. M.S. (2013). Role of Higher education in women empowerment: A study. International Journal for administrationin Management, commerce and Economics, 1, 85-90

[6] Inter-Agency Commission, WCEFA (1990). Final Report. World Conference on Education for All. Meeting Basic Learning Needs. New York: Inter-Agency Commission, WCEFA pp 45 Retrieved on $28^{\text {th }}$ March 2019 from www.unesco.org/education/pdf/11_92.pdf

[7] Ramachandran, S., \& Ganesh, C. (2019). Higher Education and Social Development in India: Prospects and Challenges, University News, 57(08), 3-5.

[8] Sandhya, S.J. (2015). Impact of Education in Women Empowerment of in Bagalkot District, Karnataka, Asian Journal of Social Sciences \& Humanities, 4(2), 87-94.

[9] Sathar, Z.A., Lloyd, C.B., \& Haque, M. (2000). Investment in Children's Education and Family Retrieved on 18-2- 2019 from http://go.worldbank.org/K9L01MQLO0

[10] Shaukat \& Pell W. A, (2015). Personal and Social problems faced by women in higher education. FWU journal of Social Sciences, 9(2). Retrieved from research gate on 18/12/2018

[11] Retrieved from Ministry of HRD Government of India Annual report 2015-16

[12] UNESCO (2010). Why Gender Equality in Basic Education in Pakistan? UNESCO: Islamabad, Pakistan

[13] Usha, S., \& Sharma, M.B. (2001). Women and higher education. New Delhi: Common wealth Publishers.

[14] Retrieved from University Grant Commission annual report 2014-15

[15] Retrieved from University Grant Commission annual report 2015-16

[16] Zafar, F. (2004). Gender Review of Education. Lahore, Pakistan: UNICEF Retrieved on 18/2/2019. 